\title{
半月板縫合後のスポーツ復帰について
}

$\begin{array}{cllll}\text { 鹿児島市立病院整形外科 } & & & \\ \text { 山 } & \text { 口 } & & \text { 聡・谷 } & \text { 良 康 } \\ \text { 牧 } & & \text { 信 } & \text { 哉・濱 } & \text { 里 } \\ \text { 雄次郎 } \\ \text { 折 }\end{array}$

\section{Return to Sports Activity after Meniscal Repair}

\author{
Satoshi Yamaguchi, Yoshiyasu Taniguchi, Shinya Maki, Yuujirou \\ Hamasato, Nobuo Origuchi, and Hiroshi Yoshimi \\ Department of Orthopaedics Surgery, Kagoshima City Hospital, Kagoshima, Japan
}

We reviewed 31 patients treated by meniscal suture from 1994 to 1998 . They consisted 19 males and 12 females with a mean age of 19.1 years (range : 10-34 years). The average follow-up period was 9.6 months (range ; 1 to 36 months). We evaluated factors about the return to sports activity after meniscal repair. The important factors are sex (female), age (after 30 years), ligament insufficiency, and type of sports (requiring jumping). The rehabilitation method shoud be considered to shorten the return period to sports activity.

Key words : meniscus suture (半月板繾合術), sports activity (スポーツ活動), meniscal tear (半月 板断裂)

はじめに

鏡視下半月板繾合術は安定した成績が得られている が, スポーツ復帰については, 切除術に比べ長い期間 を要し，様々な問題を含んでいる，本論文では，その 成績を左右する因子について検討した.

\section{対称及び方法}

1994 年より 4 年間に当院で鏡視下半月板繾合術の みを施行したスポーツ選手 31 例, 男性 19 例, 女性 12 例を対象とした。手術時年齢は 10 歳から 34 歳 （平均年齢 19.1 歳）であった. 競技種目は, ラグビー 7 例, バレーボール 6 例, バスケットボール 4 例, サッ カー 4 例, その他 10 例で, 競技レベルは, クラブ活 動 21 例, レクリエーション 6 例, 実業団 4 例であっ た. 損傷部位は, 内側半月板 21 例, 外側半月板 6 例,
両側 4 例であり, 勒帯損傷の合併は ACL11 例, MC L 2 例であった. これらの症例に対しアンヶート， あ るいは直接面談による問診を行い, 術後レベルが変わ らなかったもの (A群), 術後レベルが下がったあの (B 群)，スポーツ復帰しなかったもの（C群）に分け, スポーツ復帰の成績を左右する因子を検討した．検討 項目は，1．年齢，性別 2. JOA score 3. 勒帯 損傷 4. 競技種目 5. 復㷌までの期間とした。

\section{結果}

スポーツ復帰したものは 31 例中 26 例であり, A 群 20 例, $\mathrm{B}$ 群 6 例, C 群 5 例であった。復帰までの期 間は，2 ケ月から 6 ケ月で平均 3.7 ケ月であった. JOA score は術前平均 31.9, 術後平均 93.9 で, JOA score を各群で比較すると, C 群で術前, 術後とも に低かった（表 1 ）．性別では，A群男性 14 人（70.0 


\begin{tabular}{l|l|l}
\multicolumn{3}{|c}{ 丧 1 JOA score } \\
\hline \hline & 術前 & 術後 \\
\hline A 群 $(n=20)$ & 34.5 & 96.5 \\
\hline B 群 $(n=6)$ & 28.3 & 92.5 \\
\hline C 群 $(n=5)$ & 26.0 & 85.0 \\
\hline
\end{tabular}

\begin{tabular}{|c|c|c|c|}
\hline & $\mathrm{ACL}$ & $\mathrm{MCL}$ & total \\
\hline A 群 $(n=20)$ & 6 例 & 1 例 & 7 例 \\
\hline B群 $(\mathrm{n}=6)$ & 2 例 & 0 例 & 2 例 \\
\hline C群 $(\mathrm{n}=5)$ & 2 例 & 1 例 & 3 例 \\
\hline
\end{tabular}

\%)，女性 6 人 (30.0\%)，B群男性 4 人 $(66.7 \%)$ ，女 性 2 人 (33.3\%), C群男性 1 人 $(20.0 \%)$, 女性 4 人 (80.0\%) とC群で女性の占める割合が多かった，年 齢を年代別に分けてみる之，A群 10 代 15 人（75.0\%）, 20 代 4 人 $(20.0 \%), 30$ 代 1 人 $(5.0 \%), B$ 群 10 代 4 人 $(66.7 \%), 20$ 代 0 人 $(0 \%), 30$ 代 2 人 $(33.3 \%)$, C群 10 代 2 人 $(40.0 \%) ， 20$ 代 1 人 $(20.0 \%) ， 30$ 代 2 人 (40.0\%) と，C群で 30 代の割合が多かった.

䩗帯損傷の合併は, C 群で勒帯損賃の合併が多かっ た（表 2 ）。競技種目別にみると，バレーボール，バ スケットボールにおいて成績が悪かった（図1），復 州までの期間は，A群で 2 ケ月から 6 ケ月（平均 3.6 ケ月), $\mathrm{B}$ 群で 3 ケ月から 6 ケ月（平均 4.1 ケ月）で 2 群の間に差はなかった．C群の復帰できなかった理 由は, 膝の合併損傷によるもの 2 例, 脜以外の合併症 によるむの 2 例, 半月板症状によるもの1例であった。

\section{考察}

諸家の報告では半月板䋖合後の不良风子について様々 な報告がある．今回の我々の調查ではスポーツ復㷌を 左右する因子として，30 代に多く，女性に多い傾向 にあった．これは 30 代，女性はレクリェーショナル なスポーツをしている人が多く，術後のスポーツ復帰 には時間がかかり，復帰をあきらめてしまうケースが 多かった，復㴆までの時間の短絔により，この群の成 績を向上させることが出来ると思われる“.

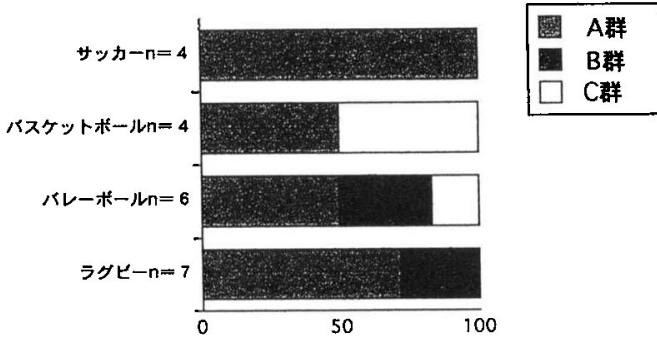

困 1 竸技程目とスポーツ復州

勒帯損傷の合併が半月板繾合後の成績を左右するこ とは周知の事実であるが，今回の調查においても勒帯 損傷例では成績が不良であり，特に ACL 合併例にお いては 3 例が後に再建術を余儀なくされた ${ }^{2) 3)}$. 又, スポーッ種目については我々の調查では跳躍系のスポー ッにおいて成績が少っており，バスケットボールにて 不良とした西山らの報告に一致する゙1). 又, contact sportsにて不良とした報告すあり，これらの半月板 へのストレスのかかるスポーッについては危険因子と して，復帰までの期間や方法などの後療法の検討が必 要であると思われる.

$$
\text { ま と め }
$$

1. 半月板繾合後のスポーツ復帰に影響する因子に ついて検討した。

2. 女性, 30 歳代, 合併損傷有, 跳躍スポーツ群 において復帰の成績が悪かった。

3. 復㷌までの期間の短縮, リハビリ法の改善が望 まれる。

\section{参 考 文 献}

1）垭部秀二, 他：半月板損傷（陳旧例）臨床スポーツ医 学監時增刊号, $8: 120-124,1991$

2）木村雅史，他：半月板損傷 (内側) 䠋床スポーツ医学 踇時增刊号，4：131-133，1987

3）木村雅史, 他：半月板繾合術の成續。関節鏡，20：3741, 1995

4）夏山元伸：半月板損傷（切除術・縫合術）. 臨床スポー “医学臨時增刊号, $10: 253-256,1993$

5) Sonne-Holm et al : Results after menisectomy in 147 athies. Acta orthop Scand $51: 303-309,1980$ 